\title{
Morphological and Physiological Changes in Transgenic Chrysanthemum morifolium Ramat. 'Ogura-nishiki' with rolC
}

\author{
Takashi Kubo ${ }^{1,4 *}$, Masato Tsuro ${ }^{2,4}$, Atsushi Tsukimori ${ }^{3}$, Yoshiaki Shizukawa ${ }^{4}$, \\ Tetsuyuki Takemoto ${ }^{5}$, Koji Inaba ${ }^{4,5}$ and Shuji Shiozaki ${ }^{6}$ \\ ${ }^{1}$ Department of Horticulture and Landscape Architecture, Hokkaido College, Senshu University, Bibai 079-0197, Japan \\ ${ }^{2}$ Faculty of Agriculture, Meijo University, Shiogamaguchi, Tenpaku-ku, Nagoya 468-8502, Japan \\ ${ }^{3}$ MARUTANE CO., LTD., Shichijo-Shinmachi, Shimogyo-ku, Kyoto 600-8691, Japan \\ ${ }^{4}$ Kyoto Prefectural Institute of Agricultural Biotechnology, Oji, Kitainayazuma, Seika-cho, Soraku, Kyoto 619-0244, Japan \\ ${ }^{5}$ Kyoto Prefectural Institute of Agriculture, Wakunari, Amarube-cho, Kameoka 621-0806, Japan \\ ${ }^{6}$ Graduate School of Life and Environmental Sciences, Osaka Prefecture University, Gakuen-Cho, Sakai 599-8531, Japan
}

\begin{abstract}
The effects of rolC on morphogenesis of Chrysanthemum morifolium Ramat. 'Ogura-nishiki' were studied. The ray flowerets in the rolC-transformed plants were shorter than those in wild-type plants, but the transformation enhanced outgrowth of lateral shoots and reduced internode elongation. Studies on adventitious shoot and root formation from leaf segments revealed that the rolC transgene led to reduced root formation but enhanced adventitious bud formation. This enhanced cytokinin-like activity was consistent with phenotypes observed in the rolC-transformed plants.
\end{abstract}

Key Words: chrysanthemum, rolC, transformation.

\section{Introduction}

The soil bacterium Agrobacterium rhizogenes causes hairy root disease in a range of dicotyledonous plants. The rolA, rolB, rolC, and rolD genes have a central role in the bacterium's ability to incite hairy roots (White et al., 1985). Schmülling et al. (1988) who investigated the biological effects of these genes in transgenic tobacco showed that overexpression of rolC decreased internode elongation and increased the number of shoots. Such alterations have also been reported for other $\mathrm{rolC}$ transformed species such as potato (Fladung, 1990; Schmülling et al., 1993), belladonna (Kurioka et al., 1992), hybrid aspen (Nilsson et al., 1996) and carnation (Zuker et al., 2001). Moreover, rolC affects the morphogenesis of plant tissues; Casanova et al. (2003) showed that rolC enhanced adventitious shoot and root formation from carnation leaves.

A number of transgenic chrysanthemum plants have been produced by using Agrobacterium-mediated transformation techniques (De Jong et al., 1994; Fukai et al., 1995; Ledger et al., 1991; Renou et al., 1993; Sherman et al., 1998a; Urban et al., 1994; Wordragen et al., 1991). Some genes that code practical

Received; May 23, 2005. Accepted; November 4, 2005.

A part of this study was presented at 2004 Autumn Meeting of the Japanese Society for Horticultural Science.

* Corresponding author (E-mail: kubo@senshu-hc.ac.jp). characteristics such as TSWV nucleocapsid gene (Sherman et al., 1998b), rice chitinase gene (Takatsu et al., 1999), BT gene (Shinoyama et al., 2002), phytochrome $B 1$ gene (Zheng et al., 2001), Arabidopsis gai gene (Petty et al., 2003) and Rice OsMADS1 gene (Jeong et al., 2002) have also been introduced to chrysanthemum.

The dwarfed, bushy phenotype, observed in rolCtransformed plants, is preferred for potted flower plants. Chrysanthemums, transformed with rolC which has the dwarfed, bush habit, have already been produced by Mitiouchkina and Dolgov (2000), but, these plants also had smaller flowers. The rolC gene introduced in their study was driven by CaMV $35 \mathrm{~S}$ promoter, which was effective throughout the plant. The rolC expression, driven by rolC native promoter, was high in root and stem, but low in leaves (Nakamura et al., 1988). This indicates that the chrysanthemums, transformed with rolC under rolC native promoter, may have the dwarfed, bushy phenotype with normal size flowers.

In this study, we transformed chrysanthemum with rolC under rolC native promoter and observed the resultant transgenic plants to evaluate the horticultural effect of this particular gene. Furthermore, adventitious shoot and root formation from leaves was investigated in rolC-transformed chrysanthemums to consider the physiological effect of rolC. 


\section{Materials and Methods}

\section{Plant material}

Chrysanthemum morifolium Ramat. 'Ogura-nishiki', which belongs to the Japanese chrysanthemum group 'Sagagiku' was used as the plant material. This cultivar shows a high regenerate ability (more than $90 \%$ of leaf segments were regenerated on MS medium, containing $5.4 \times 10^{-7} \mathrm{M}$ NAA and $8.8 \times 10^{-6} \mathrm{M} \mathrm{BA}$ ) (Tsuro et al., 2002). The aseptic shoots, cultured on $1 / 2$ Murashige and Skoog (1962) (MS) medium (half inorganic salt concentration), were used for transformation.

\section{Plant transformation}

Disarmed Agrobacterium tumefaciens LBA4404 harboring a construct prepared by replacing the sequence of the CaMV 35S promoter and $\beta$-glucuronidase gene for that of the rolC gene with an original promoter derived from pRi1724 (Handa et al., 1995) was used for transformation. Transformation was performed according to the method of Tsuro et al. (2005). Putative transformants were screened for the presence of rolC genes by PCR analysis. Genomic DNA was extracted from leaf tissue by a modified cetyltrimethylammonium bromide (CTAB) method (Rogers and Bendich, 1985). PCR was conducted by using the oligonucleotide primer pair (rolC1 and rolC2) specific for $\mathrm{rolC}$; rolC1 (5'TGATGCGATGCTTTTATGGA-3') and rolC2 (5'GGCATAAAGGTCGAAGGTCA-3') primers amplify a $330 \mathrm{bp}$ fragment. Thirty-five PCR cycles were performed in a thermal cycler (Applied Biosystem 9600, USA), by using a step-cycle program of $94^{\circ} \mathrm{C}$ for $30 \mathrm{~s}, 57^{\circ} \mathrm{C}$ for $30 \mathrm{~s}$ and $73^{\circ} \mathrm{C}$ for $30 \mathrm{~s}$.

\section{Investigation of morphological characteristics}

Two lines of transformants which showed significant morphological changes in vitro were investigated. A line of non-transformed in vitro plantlets was used as control line. Rooted plants about $3 \mathrm{~cm}$ in height were removed from the medium, and their roots were cleaned of gelrite. They were then transferred to plastic pots $(15 \mathrm{~cm}$ in diameter), filled with water-saturated Metro Mix (Scotts, USA), the plants were kept under high humidity and at $25^{\circ} \mathrm{C}$. After 2 weeks of acclimatization, 5 plants from each line were grown in a greenhouse maintained at $25^{\circ} \mathrm{C}$ under natural daylight in early March.

Twelve weeks after completion of acclimatization, the number of shoots, length of the longest shoots, and average internode length between the 5th and 10th nodes were recorded. Then, plants were grown under an 11-h photoperiod by shading with a black sheet to induce inflorescence in early August. The numbers of ray and tubular florets were counted from a random sample of 10 inflorescences (per line) and the lengths of five ray and tubular florets per inflorescence were measured. Means for transgenic and control lines were separated by using the $t$-test $(P<0.05)$.

\section{RT-PCR analysis for rolC expression}

Total RNAs were extracted from leaves and roots of wild-type and transformed plants by a modified CTAB method (Chang et al., 1993) and treated with DNase to eliminate any DNA contamination. cDNA was synthesized from $4 \mu \mathrm{g}$ of total RNA with a cDNA synthesize kit (Amersham Bioscience, USA). cDNA synthesize reaction was induced under $37^{\circ} \mathrm{C}$ for $1 \mathrm{~h}$. Expression of rolC was detected by RT-PCR by using the same primers as for detecting the transgene. Thirty PCR cycles were performed in a thermal cycler (Applied Biosystem 9600), by using a step-cycle program of $94^{\circ} \mathrm{C}$ for $30 \mathrm{~s}, 57^{\circ} \mathrm{C}$ for $30 \mathrm{~s}$ and $73^{\circ} \mathrm{C}$ for $30 \mathrm{~s}$.

Adventitious root and shoot formation from leaf explants

Leaves from the in vitro plants of wild-type and rolCintroduced were cut into $5 \times 5 \mathrm{~mm}$ segments. Sixteen explants were placed on MS medium ( $3 \%$ sucrose and $0.3 \%$ gelrite) containing $5.4 \times 10^{-7} \mathrm{M}$ NAA for root regeneration or $5.4 \times 10^{-7} \mathrm{M}$ NAA and $2.2 \times 10^{-6} \mathrm{M} \mathrm{BA}$ for shoot regeneration in 9-cm plastic plates and cultured in the dark at $25^{\circ} \mathrm{C}$. Five plates were used for each line. Root and shoot regeneration were investigated 2 and 4 weeks after culture, respectively. Means for transgenic and control lines were separated by using the $t$-test $(P<0.05)$.

\section{Results}

\section{Morphological characteristics of rolC-transformed plants}

A total of 1008 leaf segments were used for transformation, from which 23 shoots were obtained as putative transformants. Fourteen of them were confirmed as being transformants by PCR analysis (Fig. 1). The frequency of transformed plants was about $1.4 \%$. As observed in in vitro plantlets, all transformants exhibited enhanced branching and some with shortened internodes. Two lines that showed dwarf obviously, oprolC-17 and

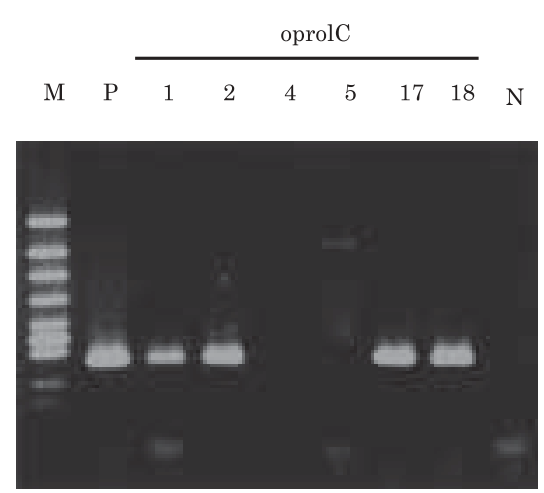

Fig. 1. Gel plate for PCR analysis of transgenic chrysanthemums ('Ogura-nishiki'). Lane M, Size marker derived from $\phi X 174$ / HaeIII; Lane P, positive control from A. tumefaciens used for transformation; Lanes oprolC, putative transformants regenerated on the medium containing $100 \mathrm{mg} \cdot \mathrm{L}^{-1}$ kanamycin; Lane N, non-transformant. 


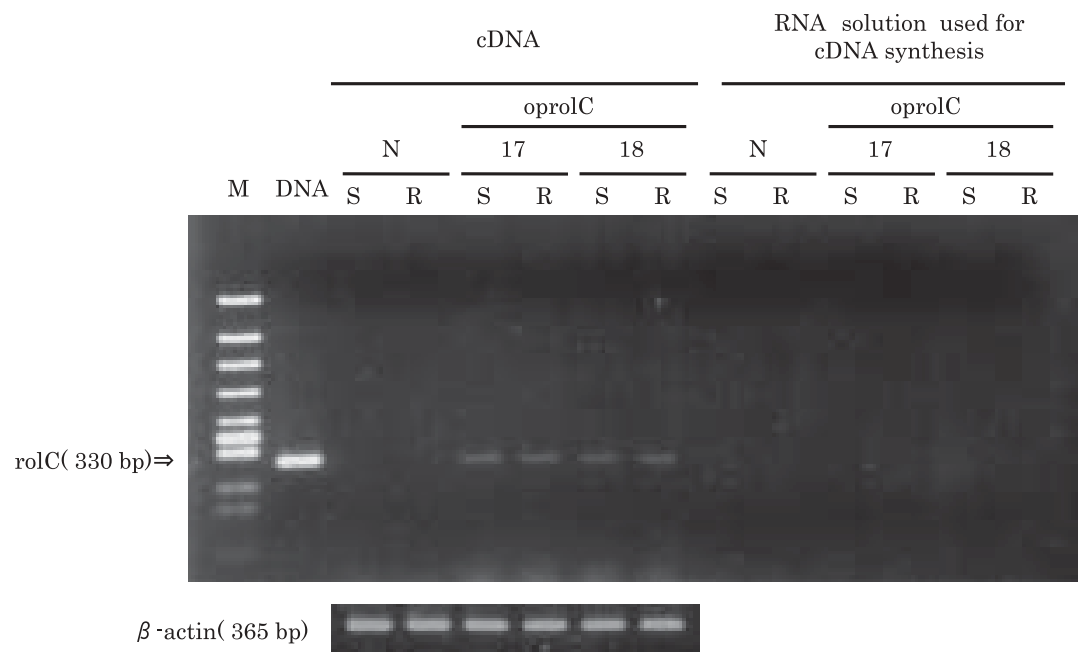

Fig. 2. Gel plates for RT-PCR analysis of rolC-transformed chrysanthemums. Total RNAs were extracted from leaves (lanes S) and roots (lanes $\mathrm{R}$ ) of wild-type, oprolC-17 and -18 plants grown in a glasshouse and used for cDNA synthesis. Lane M was size marker derived from $\phi X 174 /$ HaeIII.

-18 , were investigated morphologically.

rolC expressions in these transformants were detected in the leaves and roots of both lines (Fig. 2). Morphological differences between the wild-type and rolC-transgenic plants (Fig. 3) showed enhanced branching of both oprolC-17 and -18: the numbers of shoots were 4.2 and 3.8 , respectively, compared with 1.0 in the wild-type (Table 1). Furthermore, rolCtransgenic plants had shortened internodes: shoot lengths of oprolC- 17 and -18 were 63.4 and $39.8 \%$ of the wildtype, respectively.

Time until flowering was similar in $\mathrm{rolC}$-transgenic and wild-type plants; about 8 weeks after starting the short day treatment. The numbers of ray and tubular florets per inflorescence were not significantly different between the oprolC-17 and -18 plants and the wild-type plants (Table 2); but petal lengths of ray florets in the oprolC-17 and -18 plants were shorter than those of the wild-type plants (Table 2, Fig. 4).

\section{Adventitious root and shoot formation from leaf segments of rolC-transformed plants}

Adventitious root formation from leaf segments was reduced in oprolC-17 and -18 . Two weeks after the culture, the percentages of rooting explants were $35.0 \pm 5.8$ and $26.3 \pm 4.1 \%$ in oprolC- 17 and -18 , respectively, in comparison with $88.8 \pm 4.1 \%$ in the wildtype (Fig. 5), and the numbers of roots per regenerated explant were 1.9 and 1.7 , respectively, as compared to 4.3 in the wild-type.

Leaf segments in oprolC-17 and -18 formed more adventitious shoots. Four weeks after the culture, the percentages of adventitious shoot formation explants were $26.3 \pm 7.6$ and $31.3 \pm 3.5 \%$ in oprolC- 17 and -18 , respectively, in comparison with $6.3 \pm 2.5 \%$ in the wildtype (Fig. 5).

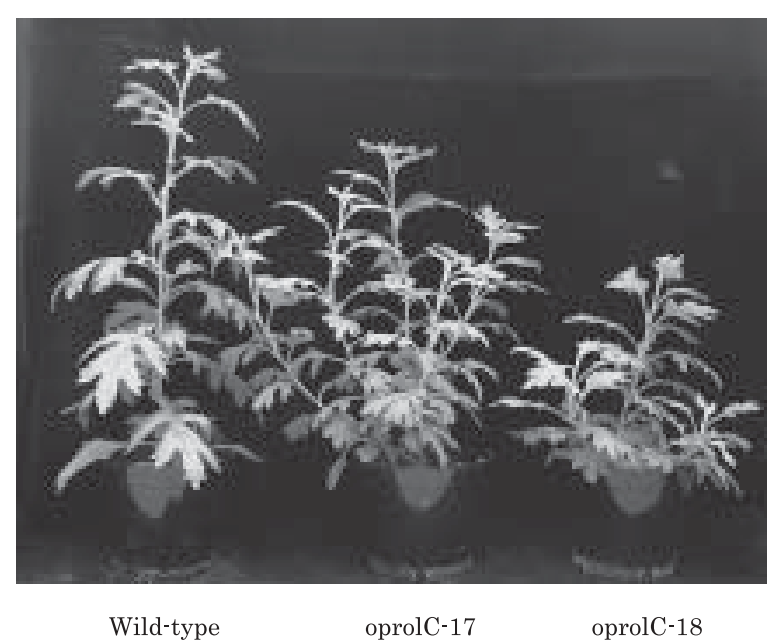

Fig. 3. Morphological differences between a wild-type and rolCtransformed plants grown in a greenhouse kept at $25^{\circ} \mathrm{C}$ for 8 weeks.

Table 1. Number of shoots, and shoot and internode lengths of wildtype and transformants 12 weeks after being transferred to a greenhouse.

\begin{tabular}{cccc}
\hline \hline & $\begin{array}{c}\text { Number of } \\
\text { shoots }^{z}\end{array}$ & $\begin{array}{c}\text { Shoot length } \\
(\mathrm{cm})\end{array}$ & $\begin{array}{c}\text { Internode length }^{\mathrm{x}} \\
(\mathrm{cm})\end{array}$ \\
\hline Wild-type & $1.0 \pm 0^{\mathrm{w}}$ & $39.9 \pm 0.6$ & $2.4 \pm 0.1$ \\
oprolC-17 & $4.2 \pm 0.2^{*}$ & $25.3 \pm 2.1^{*}$ & $1.3 \pm 0.1^{*}$ \\
oprolC-18 & $3.8 \pm 0.2^{*}$ & $15.9 \pm 2.2^{*}$ & $0.8 \pm 0.2^{*}$ \\
\hline
\end{tabular}

* indicates significant differences between $\mathrm{rol} C$-transgenic and wildtype lines according to the $t$-test $(P<0.05)$.

${ }^{z}$ Numbers of shoots over $5 \mathrm{~cm}$ were counted.

y Shoot lengths of the longest shoots were measured.

${ }^{x}$ Average values of the fifth to tenth leaves.

${ }^{\mathrm{w}}$ Means \pm SE $(\mathrm{n}=5)$.

\section{Discussion}

The rolC gene under rolC native promoter induced more lateral shoots, while reducing the internode lengths 
Table 2. Florets number and length of wild-type and transformants.

\begin{tabular}{ccccccc}
\hline \hline & \multicolumn{2}{c}{ Floret number per inflorescence } & & \multicolumn{2}{c}{ Floret length $(\mathrm{cm})^{\mathrm{y}}$} \\
\cline { 2 - 3 } \cline { 5 - 6 } \cline { 5 - 6 } & Tubular florets & Ray florets & & Tubular florets & Ray florets \\
\hline Wild-type & $68.5 \pm 6.9^{\mathrm{x}}$ & $49.8 \pm 6.1$ & & $0.73 \pm 0.08$ & $3.0 \pm 0.2$ \\
oprolC-17 & $75.8 \pm 9.6$ & $43.2 \pm 8.2$ & & $0.71 \pm 0.13$ & $2.0 \pm 0.3^{*}$ \\
oprolC-18 & $59.0 \pm 9.6$ & $43.3 \pm 6.6$ & & $0.79 \pm 0.12$ & $1.7 \pm 0.2^{*}$ \\
\hline
\end{tabular}

* indicates significant differences between rolC-transgenic and wild-type lines according to the $t$-test $(P<0.05)$.

$z$ The numbers of ray and tubular florets were counted from a random sample of 10 inflorescences.

y The length of each five of ray and tubular florets per inflorescence were measured.

${ }^{x}$ Means $\pm \operatorname{SE}(\mathrm{n}=10)$.

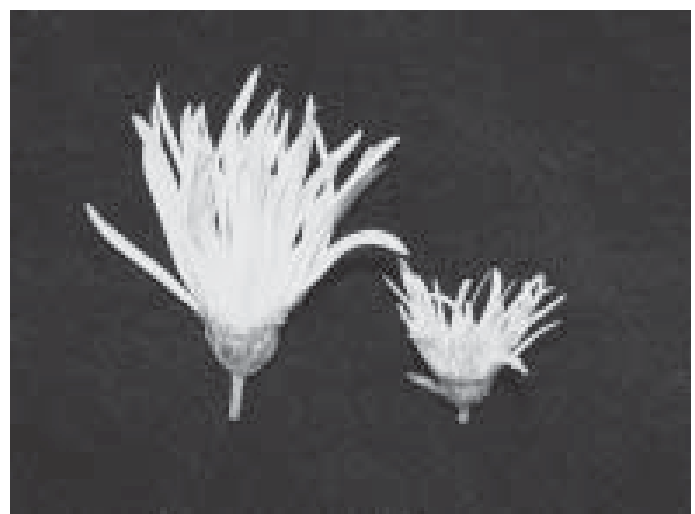

Wild-type $\quad$ rolC-transformants

Fig. 4. Morphological differences between inflorescences of a wildtype and rolC-transformant.

in chrysanthemum. The effects were similar to the effects of the rolC gene under CaMV $35 \mathrm{~S}$ promoter (Mitiouchkina and Dolgov, 2000). The purpose in this study was the production of rolC-transformed chrysanthemum with a bush phenotype but normal size flowers. But, this was not achieved as the chrysanthemums transformed with rolC under rolC native promoter had smaller size flower. Malformed leaves and flowers by introduction of the rolC gene under CaMV 35S promoter have been reported in chrysanthemum (Mitiouchkina and Dolgov, 2000), but these malformations were not detected in the chrysanthemum transformed with rolC under rolC native promoter. This promoter difference seems to have been involved in the different morphological changes. But, only 2 lines were investigated in this study; another study by Handa (1992) reported malformed leaves and flowers in plants transformed by the rolC gene under rolC native promoter. Hence, further studies are required.

The rolC transgene led to reduced adventitious root formation. Furthermore rolC-transformed chrysanthemums could regenerate from leaf segment on the medium that contains even a low concentration of cytokinin (Fig. 5). Improved shoot regeneration was also observed in rolC-transformed carnations (Casanova et al., 2003). This enhanced cytokinin-like activity is consistent with the rolC-induced phenotypes observed in our rolCtransformed chrysanthemum plants; that is enhanced outgrowth of lateral shoots and reduced elongation of internodes. Estruch et al. (1991) showed that rolC codes for a cytosolic $\beta$-glycosidase release free forms of cytokinin from their inactive glucosidic conjugates. The expression of rolC might therefore change cytokinin levels as a secondary effect during hormone metabolism.

This study showed that the introduction of rolC under rolC native promoter to chrysanthemums has advantageous effects in potted flower plants by enhancing outgrowth of lateral shoots and reducing internode elongation. However, it was simultaneously disadvantageous in that it reduced flower size.
(A)

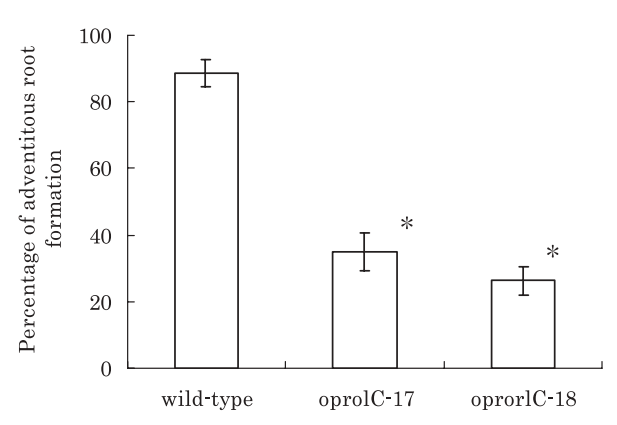

(B)

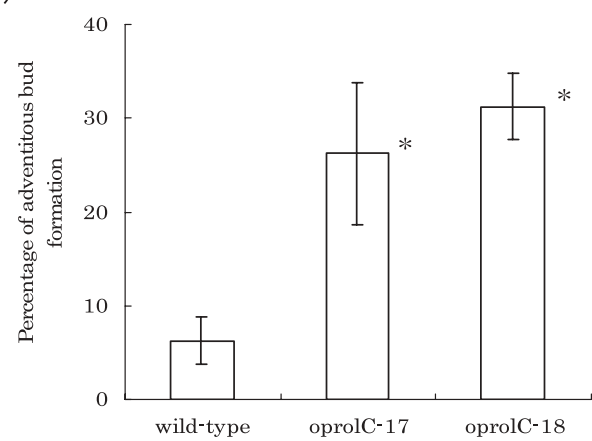

Fig. 5. Effect of transformation with rolC on adventitious root (A) and shoot (B) formation from leaf explants. Values are means \pm SE ( $\mathrm{n}=5$ ).

* indicates significant differences between rolC-transgenic and wild-type lines according to the $t$-test $(P<0.05)$. 


\section{Acknowledgments}

We thank Dr. T. Namiki, Kyoto Prefectural Institute of Agricultural Biotechnology (KAB), for reviewing this manuscript. We also acknowledge Dr. T. Handa of Tsukuba University and Dr. M. Mino of Kyoto Prefectural University for donating pBI121-op::rolC and providing sequence information on $\beta$-actin in chrysanthemum, respectively.

\section{References}

Casanova, E., A. Zukwer, M. I. Trillas, L. Moysset and A. Vainstein. 2003. The rolC gene in carnation exhibits cytokinin and auxin-like activities. Sci. Hort. 97: 321-331.

Chang, S., J. Puryear and J. Cairney. 1993. A simple and efficient method for isolation of RNA from pine trees. Plant Mol. Biol. Rep. 11: 113-116.

De Jong, J., M. M. J. Mertens and W. Rademaker. 1994. Stable expression of the GUS reporter gene in chrysanthemum depends on binary plasmid T-DNA. Plant Cell Rep. 14: 59-64.

Estruch, J. J., D. Chriqui, K. Grossmann, K. Schell and J. Sepana. 1991. The plant oncogene rolC is responsible for the release of cytokinins from glucoside conjugates. EMBO J. 10: 2889-2895.

Fladung, M. 1990. Transformation of diploid and tetraploid potato clones with the rolC gene of Agrobacterium rhizogenes and characterization of transgenic plants. Plant Breed. 109: 295-304.

Fukai, S., J. De Jong and W. Rademaker. 1995. Efficient genetic transformation of chrysanthemum (Dendranthema grandiflorum (Ramat.) Kitamura) using stem segments. Breed. Sci. 45: 179-184.

Handa, T. 1992. Regeneration and characterization of prairie gentian (Eustoma grandiflorum) plants transformed by Agrobacterium rhizogens. Plant Tissue Cult. Lett. 9: 1014.

Handa, T., T. Sugimura, E. Kato, H. Kamada and K. Takayanagi. 1995. Genetic transformation of Eustoma grandiflorum with rol genes. Acta Hort. 392: 209-218.

Jeong, J. H., D. Chakrabarty, S. J. Kim and K. Y. Paek. 2002. Transformation of chrysanthemum (Dendranthema grandiflorum Kitamura cv. Cheonsu) by constitutive expression of rice OsMADS1 gene. J. Kor. Soc. Hortic. Sci. 43: 382-386.

Kurioka, Y., Y. Suzuki, H. Kamada and H. Harada. 1992. Promotion of flowering and morphological alternations in Atropa belladonna transformed with a CaMV 35S-rolC chimeric gene of the Ri plasmid. Plant Cell Rep. 12: 1-6.

Ledger, S., E. S. C. Deroles and N. K. Given. 1991. Regeneration and Agrobacterium-mediated transformation of chrysanthemum. Plant Cell Rep. 10: 195-199.

Mitiouchkina, T. Y. and S. V. Dolgov. 2000. Modification of chrysanthemum plant and flower architecture by rolC gene from Agrobacterium rhizogenes introduction. Acta Hort. 508: 163-169.

Murashige, T. and F. Skoog. 1962. A revised medium for rapid growth and bioassays with tobacco tissue cultures. Physiol. Plant. 15: 473-497.

Nakamura, T., T. Handa, Y. Oono, K. Kanaya, M. Michikawa and H. Uchimiya. 1988. Organ-specific mRNA in transgenic tobacco plants possessing T-DNA of $\mathrm{Ri}$ plasmids. Plant Sci. 56: 213-218.

Nilsson, O., T. Moritz, B. Sandberg and O. Olsson. 1996. Expression of the Agrobacterium rhizogenes rolC gene in a deciduous forest tree alters growth and development and leads to stem fasciation. Plant Physiol. 112: 493-502.

Petty, L. M., N. P. Harberd, I. A. Carre, B. Thomas and S. D. Jackson. 2003. Expression of the Arabidopsis gai gene under its own promoter causes a reduction in plant height in chrysanthemum by attenuation of the gibberellin response. Plant Sci. 164: 175-182.

Renou, J. P., P. Brochard and R. Jalouzot. 1993. Recovery of transgenic chrysanthemum (Dendranthema grandiflora Tzvelev) after hygromycin resistance selection. Plant Sci. 89: 185-197.

Rogers, S. O. and A. J. Bendich. 1985. Extraction of DNA from milligram amounts of fresh, herbarium and mummified plant tissues. Plant Mol. Biol. 5: 69-76.

Schmülling, T., M. Fladung, K. Grossmann and J. Schell. 1993. Hormonal content and sensitivity of transgenic tobacco and potato plants expressing single rol gene of Agrobacterium rhizogenes T-DNA. Plant J. 3: 371-382.

Schmülling, T., J. Schell and A. Spena. 1988. Single genes from Agrobacterium rhizogenes influence plant development. EMBO J. 7: 2621-2629.

Sherman, J. M., J. W. Moyer and M. E. Daub. 1998a. A regeneration and Agrobacterium mediated transformation system for genetically diverse chrysanthemum cultivars. J. Amer. Soc. Hort. Sci. 123: 189-194.

Sherman, J. M., J. W. Moyer and M. E. Daub. 1998b. Tomato spotted wilt virus resistance in chrysanthemum expressing the viral nucleocapsid gene. Plant Disease 82: 407-414.

Shinoyama, H., M. Komano, Y. Nomura and T. Nagai. 2002. Introduction of delta-endotoxin gene of Bacillus thuringiensis to chrysanthemum for insect resistance. Breed. Sci. 43-50.

Takatsu, Y., Y. Nishizawa, T. Hibi and K. Akutsu. 1999. Transgenic chrysanthemum (Dendranthema grandiflorum (Ramat.) Kitamura) expressing a rice chitinase gene shows enhanced resistance to gray mold (Botrytis cinerea). Sci. Hort. 82: 113-123.

Tsuro, M., T. Kubo, Y. Shizukawa, T. Takemoto and Inaba, K. 2005. Agrobacterium rhizogenes is useful transporter for introducing T-DNA of the binary plasmid into the chrysanthemum, Dendranthema grandiflorum (Ramat.) Kitamura, genome. Plant Cell Tiss. Org. Cult. 81: 175181.

Tsuro, M., Y. Shizukawa and K. Inaba. 2002. The effects of different types of cytokinin on shoot formation and plant regeneration from leaf explants of four cultivars of Sagagiku group in chrysanthemum (Dendranthema grandiflorum (Ramat.) Kitamura). Environ. Cont. Biol. 40: 285-289. 
Urban, L. A., J. M. Sherman, J. W. Moyer and M. E. Daub. 1994. High frequency shoot regeneration and Agrobacterium-mediated transformation of chrysanthemum (Dendranthema grandiflora). Plant Sci. 98: 69-79.

White, F. F., B. H. Taylor, G. A. Huffman, M. P. Gordon and E. W. Nester. 1985. Molecular and genomic analysis of transferred DNA regions of root-inducing plasmid of Agrobacterium rhizogenes. J. Bacteriol. 164: 33-44.

Wordragen, M. F., J. De Jong, H. B. M. Huitema and H. J. M. Dans. 1991. Genetic transformation of chrysanthemum using wild type Agrobacterium strains; strain and cultivar specificity. Plant Cell Rep. 9: 505-508.

Zheng, Z. L., Z. Yang, J. C. Jang and J. D. Metzger. 2001. Modification of plant architecture in chrysanthemum by ectopic expression of the tobacco phytochrome $B 1$ gene. J. Amer. Soc. Hort. Sci. 126: 19-26.

Zuker, A., T. Tzfira, G. Scovel, M. Ovadis, E. Shklarman, H. Itzahaki and A. Vainstein. 2001. rolC-transgenic carnation with improved agronomic traits: quantitative and qualitative analysis of greenhouse-grown plants. J. Amer. Soc. Hort. Sci. 126: 13-18.

$r o l C$ 遺伝子導入による嵯峨ギク ‘小倉錦’ の形態および生理的変化

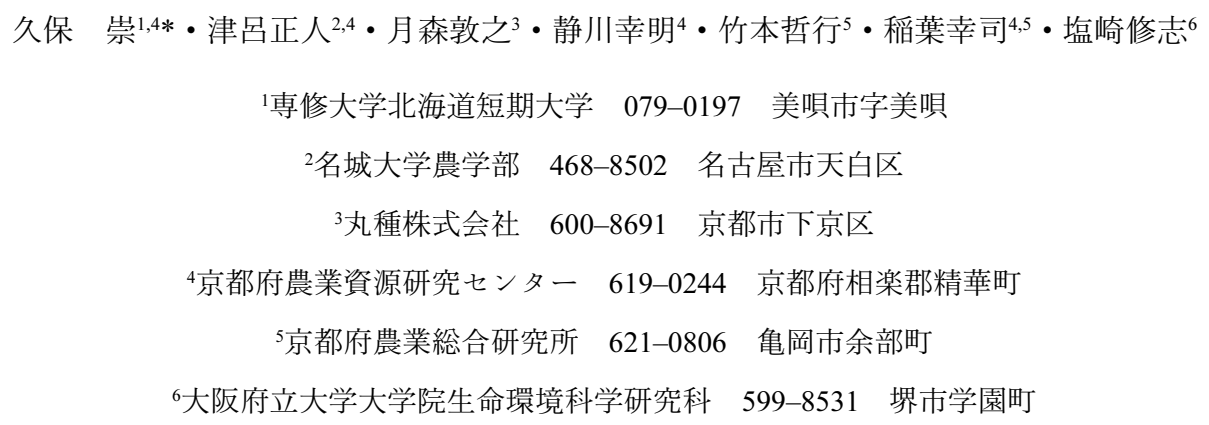

rolC 遺伝子の導入が嵯峨ギク ‘小倉錦’ の形態形成に 及ぼす影響について調查したところ, rolC 遺伝子導入に より，舌状花長の減少が認められたものの，多分枝扣よ びわい性といった鉢物に適した形質を付与できることが 示された。また，葉片からの不定芽拉よび不定根形成に
ついて調査したところ, rolC 遺伝子導入による不定根形 成の抑制抏よび不定芽形成の促進が認められた。 これら の形態掞よび生理的影響はサイトカイニンの作用に類似 して抢り, rolC 遺伝子導入による内生サイトカイニン量 の変化が示唆された. 